\title{
POLITICAL CONSTRAINTS ON EXECUTIVE COMPENSATION: EVIDENCE FROM THE ELECTRIC UTILITY INDUSTRY
}

\author{
Paul L. Joskow \\ Nancy L. Rose \\ Catherine D. Wolfram
}

Working Paper No. 4980

\author{
NATIONAL BUREAU OF ECONOMIC RESEARCH \\ 1050 Massachusetts Avenue \\ Cambridge, MA 02138 \\ December 1994
}

Support from the MIT Center for Energy and Environmental Policy Research and the National Science Foundation is gratefully acknowledged. This paper is part of NBER's research program in Industrial Organization. Any opinions expressed are those of the authors and not those of the National Bureau of Economic Research.

(c) 1994 by Paul L. Joskow, Nancy L. Rose and Catherine D. Wolfram. All rights reserved. Short sections of text, not to exceed two paragraphs, may be quoted without explicit permission provided that full credit, including $\odot$ notice, is given to the source. 


\title{
POLITICAL CONSTRAINTS ON \\ EXECUTIVE COMPENSATION: \\ EVIDENCE FROM THE ELECTRIC \\ UTILITY INDUSTRY
}

\begin{abstract}
This study explores the effect of regulatory and political constraints on the level of CEO compensation for 87 state-regulated electric utilities during 1978-1990. The results suggest that political pressures may constrain top executive pay levels in this industry. First, CEOs of firms operating in regulatory environments characterized by investment banks as relatively "proconsumer" receive lower compensation than do CEOs of firms in environments ranked as more friendly to investors. Second, CEO pay is lower for utilities with relatively high or rising rates, or a higher proportion of industrial sales, consistent with earlier research that describes political pressures on electricity rates. Finally, attributes of the commission appointment and tenure rules affect CEO compensation in ways consistent with the political constraint hypothesis: for example, pay is lower in states with elected commissioners than in states where commissioners are appointed by the governor, all else equal. Despite apparently effective pressure to constrain pay levels in this sector, however, we find no evidence of related intra-industry variation in the sensitivity of pay to firm financial performance.
\end{abstract}

Paul L. Joskow

Department of Economics

M.I.T.

50 Memorial Drive, E52-373A

Cambridge, MA 02142-1347

and NBER

Catherine D. Wolfram

Department of Economics

M.I.T.

50 Memorial Drive

Cambridge, MA 02142-1347
Nancy L. Rose

Sloan School of Management

M.I.T.

50 Memorial Drive, E52-434

Cambridge, MA 02142-1347

and NBER 


\section{INTRODUCTION}

The factors that determine the compensation of chief executive officers (CEOs) of large U.S. corporations have attracted significant academic attention during the past decade (Rosen, 1992). This interest arises for a variety of reasons. First, CEOs of large U.S. corporations control the deployment of large numbers of workers and substantial physical and financial assets. The effectiveness of the market for CEOs in allocating managerial talent within corporate hierarchies and across firms is therefore of considerable interest. Second, the dispersion of ownership suggests that the structure of compensation contracts is of considerable importance for resolving potential conflicts arising from the separation of ownership and management. Finally, nominal CEO compensation has been high and rising, and has attracted considerable attention in the debate over increased income inequality (e.g., Bok, 1993).

Both academic research and popular commentaries on CEO compensation arrangements have raised questions about the efficiency and equity attributes of CEO compensation. On one extreme are Jensen and Murphy (1990), who argue that CEO compensation is not sufficiently sensitive to firm financial performance and suggest that this may be due to political considerations that constrain the upper level of CEO compensation. ${ }^{1}$ On the other extreme is Crystal (1991), who argues that executive compensation typically is controlled de facto by the CEO rather than by the board of directors, and that as a result many CEOs are overcompensated. The arguments over excessive CEO pay are echoed in media coverage and associated public opinion polls that suggest a widespread view that CEOs of large corporations are paid too much.

Over the past two years, media attention and public reaction to reports of high CEO

${ }^{1}$ See, however, Haubrich, 1994. 
compensation levels have led Congress to change the tax treatment of CEO compensation, the Securities and Exchange Commission (SEC) to expand public reporting obligations about CEO compensation and firm performance, and the Financial Accounting Standards Board (FASB) to consider new accounting rules for stock options, which often are a significant component of CEO compensation. The real effects of this attention and political responses to it are uncertain, however. $^{2}$ To the extent that political constraints become binding, they may either limit "excessive" CEO compensation (i.e. reduce any shareholder rents appropriated by the CEO) or distort CEO performance incentives and the allocation of managerial talent by reducing compensation from efficient levels. This study investigates the presence of political constraints on CEO compensation within one sector. While we can identify the impact of various measures of political constraint on CEO compensation, we cannot determine whether these have merely redistributive effects or also have adverse efficiency consequences.

We focus our analysis on the regulated sector, and on the electric utility industry in particular. Previous research has demonstrated that CEOs of firms subject to economic regulation earn significantly less than do CEOs of unregulated firms, all else equal. ${ }^{3}$ Joskow, Rose, and Shepard (hereafter, JRS, 1993) argue that these differences reflect, at least in part, political constraints on executive compensation imposed directly or indirectly by the regulatory environment in which these firms operate. They support their argument by examining relative CEO compensation levels between regulated and unregulated firms, across industries subject to

${ }^{2}$ See, for example, Joann S. Lublin, "Firms Forfeit Tax Break to Pay Top Brass $\$ 1$ MillionPlus," Wall Street Journal, April 21, 1994, B1.

${ }^{3}$ See, e.g., Carroll and Ciscel (1982) and Joskow, Rose and Shepard (1993) and the references they cite. 
different types of regulation (e.g. state vs. federal; firm level vs. industry level), and across different organizational structures for regulated firms (e.g. multi-state holding companies vs. non-holding companies). They also explore changes in relative compensation levels over time as regulatory environments change, and differences in the sensitivity of pay to firm performance across the regulated and unregulated sectors. The results are consistent with Jensen and Murphy's (1990) argument that political constraints reduce both the level of CEO compensation and its sensitivity to firm performance.

Political constraints could affect CEO compensation in two ways. First, they may alter the basic regulatory mechanisms used in a particular industry, changing the "optimal" compensation arrangements. For example, if economic regulation reduces the complexity of the CEO's job or limits her ability to influence firm performance, it may be efficient for the boards of regulated firms to pay them less, to tie pay less closely to firm financial performance, and to hire less able CEOs. ${ }^{4}$ This would generate compensation discounts for CEOs of regulated firms relative to unregulated firms, suggesting that observed variations in pay across industries could be due, in whole or part, to unmeasured (and unmeasurable) differences in "CEO productivity" rather than direct political constraints (see JRS, 1993, and the comments by Meyer and Peltzman). Political constraints also may affect CEO compensation by placing direct political pressure on CEO compensation through the regulatory process. That is, boards of

4 Jolls (1994) demonstrates that under certain circumstances the optimal compensation contract implied by the (second-best) optimal regulatory contract involves lower compensation and compensation that is less closely tied to firm performance than would be the case for a similarly situated unregulated firm. 
directors may take regulatory and political responses to high observed CEO pay into account when they make compensation decisions.

It is difficult fully to separate these possible effects. Previous research (e.g. JRS, 1993) that relies on inter-industry comparisons necessarily captures some mixture of both. This paper attempts to isolate the direct effect of political constraints on CEO compensation by concentrating on a single industry: the U.S. electric utility industry. As discussed in JRS (1993), the characteristics of electric utility regulation are particularly conducive to exerting effective direct pressure on CEO compensation, and CEOs in this sector average considerably less compensation than their equivalent counterparts in all other industries. Further, electric utilities are for the most part regulated at the state level, and there is considerable variation in the political activism and orientation of public utility commissions, both over time and across states. The large number of electric utilities and distinct regulatory jurisdictions allows us to explore the impact of this regulatory variation within a single industry. There is, moreover, little difference in the CEO's role and activities across firms within this industry. Focusing on CEOs within a single industry therefore largely avoids the potential correlation of unmeasured $\mathrm{CEO}$ job attributes with variations in regulatory environment. By focusing on a single industry with the same basic regulatory instruments used to regulate all firms, this study is also more likely to capture the direct effects of political constraints on CEO compensation. The primary drawback to this approach is that intra-industry variation in politico-regulatory constraints is likely to be substantially less important than the inter-industry variation upon which previous studies have relied, which may make it more difficult to identify significant effects of politicoregulatory constraints. 
The empirical methodology that we employ is straightforward. We specify and estimate a standard CEO compensation equation to which we have added variables designed to capture variations in the political environment faced by electric utilities. We first examine the correlation of investment bank rankings of firm's regulatory environments with CEO compensation. These rankings characterize the relative weights that regulators give to investor and consumer interests. The political constraint hypothesis suggests that regulatory agencies that give more weight to consumer interests will be more likely to constrain CEO compensation. We next examine how economic variables that affect regulatory stringency influence compensation. Joskow $(1974,1989)$ and Hendricks (1975) have shown that regulatory constraints are more likely to be binding when firms must raise their prices to maintain their allowed rates of return. We therefore use changes in electricity rates as well as rate levels across different customer groups as indirect measures of regulatory tightness. Third, we examine the influence of customer composition on compensation, reflecting Joskow's (1972) demonstration that organized intervention in regulatory proceedings can affect the outcome of the regulatory process (see also Anderson, 1980). Finally, we examine several aspects of public utility commission (PUC) organization and composition.

Our results suggest that political pressures, operating through state regulatory commissions, influence the compensation of CEOs in the electric utility industry. Firms subject to regulation by agencies ranked as more consumer-oriented pay their CEOs less than do firms operating in regulatory environments ranked as more neutral or favorable to investors. CEOs are on average paid less when their utility's rates are high and rising than when rates are relatively low and stable or declining. This effect is most pronounced for residential rates. 
CEOs also are paid less when they serve a larger number of industrial customers, all else equal. We interpret this as reflecting the greater likelihood that industrial customers, as a group, will be able to influence the regulatory process. We also find that CEOs of utilities that operate in states where the commissioners are elected are paid less than comparable CEOs of firms operating in states where the commissioners are appointed by the governor. Other attributes of commissioner appointment and tenure rules also appear to affect CEO compensation in ways that are consistent with the political constraint hypothesis.

The remainder of the paper is organized as follows: Section 2 describes the conceptual framework used to evaluate political pressure on CEO salaries at electric utilities and discusses the variables used to measure political pressure. Section 3 describes the data and empirical specification. Empirical results are discussed in section 4, followed by a brief conclusion.

\section{REGULATORY/POLITICAL CONSTRAINTS ON CEO COMPENSATION}

The literature on the political economy of regulation describes regulatory responses to pressures exerted by competing interest groups (Stigler, 1971; Peltzman, 1976; Noll, 1989). The process through which various interest groups may influence regulatory behavior may be quite complex. We have identified a number of possible channels through which political pressures may lead to direct constraints on CEO compensation for regulated firms. ${ }^{5}$

First, and perhaps most important, high levels of CEO compensation generally are unpopular with the public, and appear to be a natural focal point for consumers, legislators, and

${ }^{5}$ Our view of how political pressures on CEO compensation can be amplified and affected through the economic regulatory process is discussed in considerable detail in JRS (1993). 
others concerned about "high" electric rates (even though the chief executive's compensation itself may be a trivial fraction of total costs for the utility). ${ }^{6}$ CEO compensation, as a "red button" that tends to attract considerable attention (and ink in the press), provides regulators with a natural opportunity to demonstrate that they are being "tough" on the regulated firms and are protecting consumer interests. This opportunity is likely to be most attractive for commissions that are more "consumer-oriented" and more responsive to interest groups seeking lower rates.

A number of investment firms systematically rate the regulatory climate faced by individual electric utilities. These rankings, which are separate from the performance ratings of a utility's equity and bonds, inform investors on the degree to which the regulatory process favors the company's ratepayers or its shareholders'.? A climate that favors ratepayers presumably will be one where there is more pressure to keep CEO salaries low. ${ }^{8}$ The ratings generally are not determined by precise mathematical formulas, but do reflect relatively objective criteria. For instance, Salomon Brothers considers state regulatory agencies' positions on: ${ }^{9}$

- the allowed return on equity,

${ }^{6}$ See, for example, Ricardo Sandoval, "Debate over Pay for Utility Execs," San Francisco Examiner, September 5, 1993, p. E-1, E-4 to E-5.

7 These rankings capture the regulation-induced risk the firm faces. For instance, a firm operating in a regulatory climate in which ratepayers are favored would be more likely to be required to absorb a large, unexpected expense (such as hurricane-related costs).

${ }^{8}$ Firms in risky settings could, in response, require more able CEOs and therefore have to offer higher salaries. Our empirical results indicate that this is not the case. This effect could, however, temper our results so that they reflect a smaller correlation between political pressure and CEO salaries than in fact exists.

9 We focus on the Salomon Brothers rankings in the empirical section because they were available to us over a longer time period than any other firms' rankings. There is no evidence that investment firm researchers consider CEO compensation directly in determining their rankings. 
- the inclusion of construction work in progress in rate base without an allowance for funds used during construction offset,

- the disallowance of construction or purchased power costs from recovery from ratepayers,

- the use of settlements to resolve outstanding requests,

- the effect of judicial decisions on the utilities,

- the use of phase-in rate increase plans,

- the time required to reach a decision, and

- the use of interim rates.

The rankings appear to provide good summary measures of the political environment created for an electric utility by its regulators. We expect that political pressures from the public, as mediated through the legislature, executive, and regulatory process, will be more aggressively articulated in regulatory environments that are characterized as "pro-consumer" using rankings such as these. ${ }^{10}$

Second, political pressures are likely to be more effective when there is a convenient local public forum that both highlights executive compensation and provides a mechanism to "punish" firms perceived to pay their CEOs "too much."11 Formal rate hearings provide such a forum. Joskow (1974) and Hendricks (1975) demonstrate that regulatory constraints are more likely to bind when firms are involved in formal regulatory rate reviews, which tend to be more

${ }^{10}$ Other investment banks rank states instead of individual utilities. Rankings for individual firms are important to us for two reasons. First, they account for utilities that operate in more than one state and, therefore deal with more than one regulatory commission. Second, occasionally the rankings capture variations within a state in the relationship between different utilities and the regulatory commission. For instance, there are six utilities in our data set that operate exclusively in New York. In 1980 and 1981, Long Island Lighting Company was ranked below the rest of the New York utilities, presumably as it attempted to wrestle Shoreham, its nuclear power plant, into its rate base.

11 Punishment may, for example, take the form of excluding all or part of executive compensation from recoverable costs, or using low-end estimates of capital costs to calculate allowable rates of return. 
frequent when rates are rising than when they are stable or declining.

Third, political pressures on compensation are likely to be more intense when interest and participation in regulatory proceedings are high. Active participation in rate hearings by consumer groups can provide direct pressures on regulators to constrain visible CEO compensation along with other costs. ${ }^{12}$ Participation and interest generally appear greatest when rate increases are large, even if rate levels are relatively low, and when overall rate levels are relatively high, even if rates are not increasing particularly rapidly. For example, in states such as California and New York, with high nominal rates, consumer groups appear to be much more active in regulatory proceedings than they are in states with low nominal rates. ${ }^{13}$

Relative rates across customer groups and customer mix are likely to affect the intensity of these constraints. Residential rates are likely to be a significant determinant of political pressure. Residential customers tend to be represented by a designated government official, such as the state attorney general or a state corporate counsel, ${ }^{4}$ and therefore are represented regardless of their number. For non-residential customers, participation and influence in rate hearings is likely to depend not only on rates but also on the size of the group in the utility's customer base. Industrial users often find it worthwhile to represent themselves as a group,

${ }^{12}$ See California Public Utilities Commission Decision 91-12-076, 1991, pp. 40-44.

13 It is also of interest that most of the recent regulatory activity focused on restructuring and on retail competition in the electric power industry has occurred in states with relatively high electric rates (e.g., California, New York, Connecticut, and Rhode Island) or in states with powerful industrial groups (e.g., Michigan).

${ }^{14}$ Some states (e.g. California) have active, independently-organized consumer groups that represent either residential or large industrial customers in regulatory proceedings. 
since their interests may conflict with those of residential customers. ${ }^{15}$ The incentive to organize and effectiveness of this representation are likely to depend not only on industrial rate levels and changes, but also on the importance of industrial customers in the utility's business and the average size of its industrial customers. ${ }^{16}$ Finally, because residential and industrial customers tend to be better represented than commercial customers in utility regulatory rate proceedings, political pressures on regulators are probably more dependent on rates for these classes than on rates for commercial or other customer classes. ${ }^{17}$

These factors suggest that companies with rising rates and those with relatively high rate levels will face more severe regulatory and political pressures on a broad set of cost components, including CEO compensation. ${ }^{18}$ Those utilities with more significant industrial sales and larger industrial customers also are likely to face greater constraints on costs and possible executive compensation levels.

Fourth, the rules governing how regulators are selected and the attributes of their appointments may affect their sensitivity to political pressures over executive compensation. For

is This conflict makes it risky for industrial users to rely on the government representative.

16 Large industrial users may be able to influence utilities directly; their interests need not be mediated through the regulatory agency. For instance, they may threaten to self-generate if rates are "too high."

${ }^{17}$ The relative lack of political clout of the commercial class is consistent with the widely held view (in the U.S. as well as other countries) that margins tend to be higher for commercial customers (given the operating and capital costs incurred to serve them) than for other customer classes.

18 Rate levels may be positively correlated with CEO salaries through, for example, geographic market effects. Utility in high cost areas are likely to have both high rates and high labor costs, including high executive salaries: compare, for instance, Boston Edison to Montana Power. Our empirical analysis conditions on such utility-specific effects in the regression models. 
example, elected commissioners may be more sensitive to public concern and more interested in making "high profile" cost disallowances that will attract media attention. Longer term lengths for commissioners could reduce their susceptibility to such political pressure. Commissioners' backgrounds (such as previous public or private sector employment) also may influence their predisposition toward constraining executive compensation. Precisely how commission- and commissioner-specific attributes interact with one another to mediate political pressures is uncertain, however. Navarro (1982) demonstrates that regulatory rankings by investment bankers are weakly associated with these types of measures, although research that examines the effects of these attributes on prices, rates of return, and costs is fairly inconclusive. ${ }^{19}$ We analyze whether and how a variety of commission attributes affect CEO compensation levels.

\section{DATA AND EMPIRICAL MODEL}

Our empirical compensation equation models salary and bonus as a function of the political pressure faced by a utility, firm and CEO characteristics, and time and firm-specific fixed effects. The specification, based on relatively standard compensation equations in the literature, is similar to models used by JRS (1993) and Joskow and Rose (1994):

19 See Hagerman and Ratchford (1978), Smiley and Greene (1983), Costello (1984), and the references they cite. 


$$
\begin{aligned}
& \ln \left(\operatorname{SALARY}_{i j t}\right)=\beta_{1} * \text { CEOTENURE } \text { TEj }_{i}+\beta_{2} * A P T . A G E_{i j}+\beta_{3} * \text { OUTSIDER }_{i j} \\
& +\beta_{4} * \text { MKT. RETURN } j_{1}+\beta_{5} * \text { MKT. RETURN } j_{j,-1}+\beta_{6} * M K T . R E T U R N_{j,-2} \\
& +\beta_{7} * \operatorname{EXEMPT}_{j t}+\beta_{8} * \text { DIVERSE }_{j t} \\
& +\beta_{9} * \ln \left(\text { ASSETS }_{j t}\right)+\beta_{10} * \ln \left(\text { EMPLOYEES }_{j t}\right) \\
& +\beta_{11} * \text { POL. PRESSURE MEASURE } E_{j t}+\gamma_{t}+\mu_{j}+\epsilon_{i j t}
\end{aligned}
$$

for CEO $\mathrm{i}$ in firm $\mathrm{j}$ and year t. $\gamma_{\mathrm{t}}$ is a year-specific effect that reflects compensation trends common to all electric utilities in a given year, $\mu_{\mathrm{j}}$ is a firm-specific error, and $\epsilon_{\mathrm{ijj}}$ is a random disturbance term assumed to be orthogonal to the rest of the model.

Our data set is an unbalanced panel of observations on 87 companies over 1978-1990. ${ }^{20}$ The variables included in the analysis are described below, and their summary statistics are reported in Table 1. All dollar amounts are in constant 1990 dollars unless otherwise noted.

\section{CEO Compensation}

The dependent variable is the natural logarithm of the CEO's annual salary and bonus, $\ln (\operatorname{SALARY})$. The primary source for this variable was Forbes' annual survey of CEO compensation, as compiled by JRS (1993). Approximately 65 electric utilities are represented in these data. We supplemented the JRS (1993) data with information from proxy statements to increase the number of utilities covered in our data set to 87 .

Executive compensation typically includes a number of components, which may include base salary, cash bonus, deferred compensation, corporate contributions to a savings plan, a

20 Our sample was limited to the companies and time period for which Salomon Brothers rankings were available. 
variety of benefits and perks, stock awards, and stock options or appreciation rights. Forbes reports compensation in three main categories: salary and bonus, gains from the exercise of stock options or appreciation rights, and other compensation. We have replicated these categories with information from proxy statements to the extent possible. Our analysis focuses on salary and bonus, as the proxy statements consistently provide sufficient information to replicate salary and bonus, but not always enough detail to re-create the other components of total compensation. For electric utilities, salary and bonus captures almost all of a CEO's compensation (on average 95 percent in our sample), and results using total compensation are essentially identical to those reported below.

\section{CEO Characteristics}

We control for a number of CEO characteristics that have previously been found to affect CEO compensation (see, e.g., Rosen, 1992, and JRS, 1993). These include the CEO's age at the time he $\mathrm{e}^{21}$ was appointed to his current position (APT. $\left.A G E\right)$, his tenure in office (CEO TENURE) and an indicator variable equal to one if the CEO was hired from outside the utility, as opposed to promoted from within the corporate hierarchy (OUTSIDER). ${ }^{22}$ These data are available in the Forbes survey or the proxy statements, depending on the source for the salary observation.

21 None of the CEOs in the data set is female.

${ }^{22}$ Following JRS (1993), a CEO is defined to be an outsider if he was employed by the company for three or fewer years before becoming CEO. 


\section{Firm Characteristics}

We control for a number of firm characteristics that are likely to affect CEO compensation levels. These include firm size, financial performance, and measures of organizational structure, as well as firm-specific effects. Firm size and financial performance data were obtained from the COMPUSTAT Utility Tapes. Information on organizational structure was based on a review of utility annual reports, 10K filings, and financial analysts' reports on utility diversification.

Perhaps the most consistent finding in the CEO compensation literature is the strong and precise positive relationship between firm size and CEO pay (Rosen, 1992, and references cited therein). Firm size typically is measured by revenues, although alternative indicia such as assets and employees may capture inter-industry differences in firm scale, organization and management requirements (JRS, 1993). For consistency with JRS (1993), we use ASSETS and EMPLOYEES as the measure of firm size. ${ }^{23}$

An extensive literature investigates the influence of firm financial performance on executive pay (see Rosen, 1992, and Joskow and Rose, 1994, for references). Firm financial performance in this study is measured by stock market rates of return. Following Joskow and Rose (1994), we include current, one-, and two-year lags in returns. Specifications that include accounting returns do not add significantly to the explanatory power of our model for our sample

\footnotetext{
${ }^{23}$ Most coefficients are robust to measuring scale by either revenues or assets and employees. Because firm revenues are quite correlated with rate levels, however, the coefficients on firm size and rate levels both change when scale is measured by revenues. Implied scale elasticities are roughly constant across specifications for assets and employees.
} 
of utility executives. ${ }^{24}$ We also explore specifications that allow the coefficients of the return variables to depend on the regulatory environment. These provide an intra-industry test of Jensen and Murphy's (1990) hypothesis that the link between executive pay and firm performance is weakened by political constraints on the upper end of compensation. ${ }^{25}$

Our final firm characteristics are two variables that capture attributes of a utility's organizational structure: EXEMPT and DIVERSE. EXEMPT is an indicator variable equal to one if the utility is organized as an exempt holding company under the Public Utility Holding Company Act of 1935. The holding company structure implies that the CEO is the chief executive of the holding company, not solely of the regulated electric utility. If this enables the company to "shelter" part of the CEO's compensation from direct regulatory review, EXEMPT should be positively correlated with CEO compensation. Reorganization into exempt holding companies, so that a holding company became the parent of the regulated utility, became relatively popular during the 1980 s.

The holding company structure also facilitates diversification into non-utility businesses by affecting a clear separation between the utilities regulated and unregulated activities. DIVERSE, which captures the extent to which this diversification was pursued by the utility, is a dummy variable set equal to one if the utility has achieved "significant diversification" into

${ }^{24}$ This contrasts with the strong role that accounting returns appear to play in results for regulated industries overall (JRS, 1993) and in unregulated industries (e.g., Lambert and Larcker, 1987, Sloan, 1993, and Joskow and Rose, 1994). This null result is particularly surprising given the focus of utility regulation and many utility managerial compensation contracts on accounting rates of return.

${ }^{25}$ The results in JRS (1993) suggest that the pay-for-performance relationship is weaker for regulated industries than it is for unregulated industries, consistent with this argument. 
non-utility lines of business. ${ }^{26}$ Diversification may affect compensation through both changes in the CEO's inherent productivity and relaxation of regulatory constraints, both of which imply positive correlations between DIVERSE and compensation. Managing substantially diversified enterprises may require greater skills on the part of the CEO; firms that diversify into non-utility businesses therefore may have to pay more to attract CEOs with the necessary qualifications (Rose and Shepard, 1994). At the same time, regulatory pressures on CEO compensation may be reduced by diversification. For example, the availability of non-utility revenues may enable a firm to charge part (or even all) of the CEO's compensation to unregulated subsidiaries, removing it from direct regulatory review.

The interpretation of results for these organizational variables may be cleanest for exempt holding companies that have not undertaken significant diversification (EXEMPT equals one, DIVERSE equals zero). In these firms, the job of the CEO remains largely unchanged. The holding company structure may, however, provide a rationalization for higher CEO pay and an opportunity to obscure the magnitude of total compensation in rate proceeding by charging part of the CEO's salary to unregulated affiliates and reducing the amount charged to the regulated utility. If this effect is important, we expect a positive coefficient on EXEMPT in models that control for the value of DIVERSE.

\section{Regulatory and Political Environment}

Our primary measure of regulatory environment is Salomon Brothers' rankings of

${ }^{26}$ This assessment is based on our review of the sources described earlier. Among the factors we considered were the fractions of revenues, costs, and assets in non-utility businesses, discussions of diversification plans in annual reports, and perceptions of stock analysts. 
utilities' regulatory climates. ${ }^{27}$ The rankings, available twice-annually between 1978 and 1990 , rate the political climate facing individual utilities using a 13-part letter scale ranging from $\mathrm{A}$ to $\mathrm{E}$ (with pluses and minuses). SALOMON BROS is the annual average of a numerical transformation of the letter grades (where A, representing a utility-friendly climate, is one and E, representing a climate that favors ratepayers, is thirteen). The higher the value of SALOMON $B R O S$, the more consumer-oriented is the commission and, according to our hypothesis, the lower will be CEO compensation. We report estimates of the compensation equation in which the Salomon Brothers rankings enter linearly, though we also examine the pattern of coefficients on separate dummy variables for each grade.

Our second set of measures, reflecting variations in rates and customer mix, are from the COMPUSTAT Utility Tapes. Residential (RES. RATE) and industrial (IND. RATE) rates were calculated by dividing a company's total residential (industrial) revenue by its total kilowatt-hour sales to residential (industrial) customers. ${ }^{28}$ RES. RATE GROWTH and IND. RATE GROWTH measure the nominal growth rate in the residential and industrial rates, and are defined as the ratio of current rates to the previous year's rates, minus one. IND. CUSTOMERS is the fraction

${ }^{27}$ Salomon Brothers' rankings are available for a longer period than other rankings and are assigned to individual utilities. We also experimented with Merrill Lynch rankings of the states' regulatory climates, assigning a sales-weighted average ranking to firms that operate in more than one state. These rankings were only available for 1985 and later. Our results were very similar to results using the Salomon Brothers rankings, but are much less precisely estimated due to the shorter time period.

28 This construction implies that rates will reflect usage patterns. For instance, since electric utilities charge industrial customers both for energy and capacity use, a utility whose industrial customers have high capacity and low energy needs will appear to have high rates. We assume that customers' usage patterns are fixed over time, so the firm-fixed effects eliminate this phenomena. Moreover, there is no theoretical link between usage charges and CEO salaries. 
of a utility's total customers that are industrial users, and IND. AVG. USE is the per cap consumption in gigawatt-hours.

The final set of regulatory variables reflect characteristics of each state's regulato agency, and were obtained from annual issues of the National Association of Regulatory Util: Commissioners' Annual Report on Utility and Carrier Regulation, 1978-1990. For multi-st: utilities, the data were transformed from state-level data to firm-level data using weights ba: on the proportion of the utility's sales in each state..$^{29}$ These variables include: ELECTE equal to one for states with elected public utility commissioners; $\ln (C H A I R S A L A R Y)$, 1 natural $\log$ of the state public utility commission chairs' salary; $;^{30} T E R M$, the length commissioners' terms; NO QUALIFICATIONS, equal to one for states that do not have statut qualification requirements for commissioners; and PUBLIC, equal to one for states that have or more commissioners previously employed in the public sector, for instance, as a st legislator.

\section{EMPIRICAL RESULTS}

Results from specifications that include the Salomon Brothers' rankings and measures a utility's economic climate are summarized in Table 2 . Because preliminary analysis suggest strong correlations between the firm-specific errors and several of the independent variables.

29 The weights are constructed from data for 1988, the earliest year for which 1 Department of Energy Energy Information Administration published sales breakdowns by stat Because companies sales by state are relatively constant over time, we did not vary the weis: except to make adjustments for companies that acquired an operating subsidiary in a new st: during our sample period.

30 If a range was reported for the chair's salary, we took the mid-point of the range. 
specifications are estimated with year- and firm-fixed effects. ${ }^{31}$ The coefficients on CEO and firm characteristics are quite stable across all specifications, and the estimates are similar to those of previous studies (see Rosen, 1992, and JRS, 1993). The estimated coefficients on the regulatory variables generally are consistent with the predicted negative signs for all variables.

The results for $S A L O M O N B R O S$, which are robust to the inclusion of the economic climate variables, suggest that regulatory environments that favor ratepayers over shareholders are associated with low CEO salaries. The magnitude of the coefficient (.023 to .026 , with a standard error of about .006) implies that a two-step improvement in a utility's grade, for example from $\mathrm{C}$ to $\mathrm{B}-$, is associated with a four to five percent increase in the CEO salary. ${ }^{32}$

We also have explored specifications in which SALOMON BROS. is not constrained to have a log-linear effect on compensation. Figure 1 compares the impact of SALOMON BROS. when the rankings enter the $\log$ (compensation) equation linearly (represented by the solid line) with the pattern of effects estimated from separate dummy variables for each grade level (represented by the circles, which are scaled to reflect the number of observations in each category). The results suggest some non-linearity, with the most consumer-oriented commissions

31 The results are quite sensitive to the inclusion of firm-specific effects, and the exogeneity of these effects were rejected for every set of results in Tables 2 and 3 (Hausman (1979)). We also explored specifications that included CEO-specific rather than firm-specific effects. The coefficients on the regulatory/political pressure variables were robust to this change, but the larger number of fixed-effects to be estimated (183 CEOs rather than 87 firms) substantially reduced their precision.

32 The change from $\mathrm{C}$ to $\mathrm{B}$ - is equivalent to a move from 7 to 5 using our scaling of SALOMON BROS. This represents a reduction in the variable of about one standard deviation from its mean of 6.6 . 
having proportionately larger impacts on CEO compensation. ${ }^{33}$

Columns II through VI explore the impact of current rate levels and rate growth over the previous two years on CEO compensation. Columns II and III report results for residential rates: II includes only the level of residential rates, III includes both levels and growth. Residential rate levels have a strong negative effect on CEO compensation in both specifications, although the impact is somewhat smaller once we control for rate changes. The results in column II imply an elasticity of compensation with respect to residential rate levels of $17 \%$ (standard error, $9 \%$ ), suggesting that a utility with residential rates $20 \%$ higher than those of an otherwise comparable utility will pay its CEO on average $3.5 \%$ less. ${ }^{34}$ Nominal rate growth has an additional depressive effect on CEO compensation, with most of the impact coming from lagged rate growth. The coefficient on RES RATE GROWTH, $t-1$ implies that an increase of 10 percentage points in the nominal growth rate (e.g., from 5 percent to 15 percent, about one standard deviation from the mean) reduces CEO compensation by about $2 \%{ }^{35}$ These results provide strong support for the hypothesis that high and increasing rates both intensify political pressures on regulatory agencies and lead to the compression of CEO salaries.

We repeat the rate analysis for industrial rates in columns IV and V. Although the patterns are quite similar to those for residential rates, the estimated coefficients are smaller and

${ }^{33}$ Other nonlinear specifications for SALOMON BROS., including quadratic and cubic models, failed to yield substantial improvements in fit. The coefficients on the other variables in Table 2 were insensitive to these alternative specifications.

34 This increase represents slightly less than one standard deviation from the mean rate level.

35 Because the model includes year fixed-effects, the coefficients on the growth variables are identical to those that would be estimated from real growth rates. 
cannot be statistically distinguished from zero. We combine the analysis of residential and industrial rates in column VI, which includes rate levels, growth and lagged growth for both classes of users. The high degree of correlation between residential and industrial rates makes it difficult to estimate the individual coefficients with any precision. ${ }^{36}$ The point estimates suggest, however, that residential rather than industrial rate levels and growth may be the more important determinant of political pressure on executive compensation. ${ }^{37}$

Column VII adds IND. CUSTOMERS, the proportion of a utility's total customers that are industrials, and IND. AVG. USE, the industrial per capital gigawatt-hour consumption to the model in VI. These variables are intended to capture differences in industrial user organization and influence. The coefficient on IND. CUSTOMERS is large and negative. A one standard deviation increase (one percentage point) in the proportion of a utility's customers that are industrial users reduces CEO compensation by $2.8 \%$ (standard error, $1.4 \%$ ), all else equal. The coefficient on IND. AVG. USE is negative, but statistically and economically insignificant. ${ }^{38}$

${ }^{36}$ Rate levels are correlated at the .889 level; rate growth at the .877 level.

37 Some additional support for this view is provided by specifications that include commercial and "other customer" rate variables. In the simple rate level specification (such as column II), including rate levels for all four customer groups yields the following results:

$$
\begin{aligned}
& \beta_{\ln (\text { RES. RATE) }}=-0.381(0.190) \\
& \beta_{\ln (\text { COMM. RATE) }}=0.376(0.244) \\
& \beta_{\ln (\text { IND. RATE })}=-0.055(0.145) \\
& \beta_{\ln (\text { OTHER RATE })}=-0.025(0.021)
\end{aligned}
$$

The data do not reject the restriction that the coefficients on industrial, commercial, and other rates are all zero $(\mathrm{F}(3,737)=1.48)$.

38 At the point estimate of $-.0003(.0015)$, a one standard deviation increase in industrial per capita use would reduce CEO compensation by .2\% 
In addition to the specifications reported in Table 2, we have estimated models that allow the pay-for-performance sensitivity as well as compensation level to depend upon the regulatory environment. These models attempt to test Jensen and Murphy's (1990) hypothesis that political pressures prevent salaries from being too strongly linked to stock market returns. We have implemented this by including interactions of either SALOMON BROS or $\ln (R E S$. RATE) with the market return variables. ${ }^{39}$ There is no evidence that regulatory variation influences the payfor-performance relationship within the utility industry, as the coefficients on the interaction terms were for the most part zero and statistically insignificant. We recognize that intra-industry variation may not provide a very powerful test of the Jensen and Murphy hypothesis, however.

Finally, we analyze the effect of state public utility commission and commissioner attributes on executive compensation. While the theory linking these attributes to the consumer or investor orientation of the agency is not well-developed, we include in Table 3 the expected signs of the relationships that we infer from the previous literature's discussion and results (see Navarro, 1982; Hagerman and Ratchford, 1978; Smiley and Greene, 1983 and Costello, 1984). ${ }^{40}$ The coefficient estimates reported in Table 3 generally bear out the conjectured relationship between the commission attributes and CEO salaries. CEOs of utilities in states with elected commissions are paid less than are CEOs in states where commissions are

39 We have also experimented with interactions of market return variables with dummy variables categorizing the regulatory regime (e.g., Salomon grades above or below various cutoffs).

40 None of these studies analyzed a variable similar to PUBLIC. Following the reasoning behind the coefficient on ELECTED, we hypothesize that commissioners who were previously employed in the public sector (for example, as state senators) will be more sensitive to public sentiment and, therefore, less likely to regulate highly-paid CEOs. 
appointed. The coefficient on ELECTED in Column VIII implies that a CEO whose company operates in a state with elected commissioners earns $18 \%$ less than a similarly-situated CEO whose company operates in a state with appointed commissioners. The coefficients on the other variables tend to be less significant in both economic and statistical terms. For example, a one year increase in the term of the commissioners who regulate a utility implies a $1.5 \%$ increase in compensation. ${ }^{41}$

Columns IX and X introduce SALOMON BROS and the rate level and growth variables, respectively. Except for $\ln (C H A I R S A L A R Y)$, the coefficients on the commission attribute variables are relatively robust to the inclusion of these variables. Further, the coefficient on SALOMON BROS in Columns IX and $\mathrm{X}$ are similar to the coefficient on this variable in a specification in which it is the only political pressure variable. ${ }^{42}$ This indicates that the Salomon Brothers rankings capture attributes of a utility's political environment beyond those that are captured by the commission and commissioner attributes.

\section{CONCLUSION}

We find strong evidence that CEO compensation within the electric utility industry changes with the regulatory environment in which firms operate, consistent with the operation

${ }^{41}$ The results in Table 3 are sensitive to the inclusion of firm-fixed effects, and should be interpreted with caution. The coefficients are identified from intra-firm time series variation in the variables, which tends to be quite limited for the commission attribute variables. For example, only five utilities record changes in ELECTED during the time period covered by our data set.

42 In a specification identical to the one reported in Column I of Table 2 run on the subsample of the data set used in Table 3, the coefficient on SALOMON BROS was -0.020 (0.005). 
of political pressures that place significant constraints on executive compensation. CEOs are paid less when their firms operate in regulatory environments that favor consumers over company shareholders. They are paid less when their rates, particularly residential rates, are high, and less when their rates are rising rapidly, even from a relatively low base. CEOs of utilities operating in states with elected commissioners are paid significantly less than CEOs operating in states with appointed commissioners. Overall, these results are consistent with the use of the regulatory process to highlight and constrain CEO compensation.

These findings amplify and reinforce the conclusions reached by JRS (1993) in their inter-industry study of regulatory effects on executive pay: Economic regulation appears to provide an effective mechanism through which public concerns about executive compensation can be translated into political and regulatory action, and ultimately into reduced CEO pay. This suggests that recent efforts by Congress, the SEC, and FASB to increase the visibility of CEO compensation may further increase the political pressures on CEOs across all industries, and may provide some additional constraint on compensation arrangements. Whether this limits the ability of CEOs to extract excessive rents from their boards of directors or leads to adverse incentive and allocative effects by reducing compensation from optimal levels depends on the relation of unconstrained compensation levels to optimal compensation arrangements. Without credible research results on this question, the welfare effect of additional political constraint on executive pay will remain unknown. 


\section{REFERENCES}

Anderson, Douglas. 1980. "State Regulation of Electric Utilities." In James Q. Wilson, editor, The Politics of Regulation, pp. 3-41. New York: Basic Books.

Bok, Derek. 1993. The Cost of Talent. New York: The Free Press.

Carroll, Thomas, and David Ciscel. 1982. "The Effects of Regulation on Executive Compensation." Review of Economics and Statistics 64 (August): 505-9.

Costello, Kenneth. 1984. "Electing Regulators: The Case of Public Utility Commissioners." Yale Journal on Regulation 2: 83-105.

Coughlan, Anne, and Ronald Schmidt. 1985. "Executive Compensation, Management Turnover, and Firm Performance: An Empirical Investigation." Journal of Accounting and Economics 7 (April): 43-66.

Crystal, Graef S. 1991. In Search of Excess. New York: Norton.

Gibbons, Robert, and Kevin J. Murphy. 1990. "Relative Performance Evaluation for Chief Executive Officers." Industrial and Labor Relations Review 43 (February Supplement): S30-S51.

Hagerman, Robert. and Brian Ratchford. 1978. "Some Determinants of Allowed Rates of Return on Equity to Electric Utilities." Bell Journal of Economics 9 (Spring): 46-55.

Haubrich, Joseph G. 1994. "Risk Aversion, Performance Pay, and the Principal-Agent Problem." Journal of Political Economy 102 (April): 258-276.

Hausman, Jerry. 1978. "Specification Tests in Econometrics." Econometrica 46 (April): 12511272.

Hendricks, Wallace. 1975. "The Effects of Regulation on Collective Bargaining in Electric Utilities." Bell Journal of Economics 6 (Autumn): 451-465.

Jensen, Michael, and Kevin J. Murphy. 1990. "Performance Pay and Top-Management Incentives." Journal of Political Economy 98 (April): 225-64.

Jolls, Christine, "Managerial Contracts at Regulated Firms," mimeo, September 6, 1994.

Joskow, Paul. 1972. "The Determination of the Allowed Rate of Return in a Formal Regulatory Hearing." Bell Journal of Economics and Management Science, 3:632-644.

1974. "Inflation and Environmental Concern: Structural Change in the Process of Public Utility Price Regulation." Journal of Law and Economics 17 (October): 291-327. 
. 1989. "Regulatory Failure, Regulatory Reform, and Structural Change in the Electric Power Industry." Brookings Papers on Economic Activity: Microeconomics, 1989: 125-99.

Joskow, Paul, and Nancy Rose. 1994. Pay-for-Performance: A Reassessment. Mimeo, MIT.

Joskow, Paul, Nancy Rose, and Andrea Shepard. 1993. "Regulatory Constraints on CEO Compensation." Brookings Papers on Economic Activity: Microeconomics, 1993: 1-58.

Laffont, Jean Jacques and Jean Tirole. 1993. A Theory of Incentives in Procurement and Regulation. Cambridge: MIT Press.

Lambert, Richard, and David Larcker. 1987. "An Analysis of the Use of Accounting and Market Measures of Performance in Executive Compensation Contracts." Journal of Accounting Research 25 (Supplement): 85-125.

Meyer, John. 1993. Comments. Brookings Papers on Economic Activity: Microeconomics, 1993: 59-62.

Murphy, Kevin J.. 1985. "Corporate Performance and Managerial Remuneration: An Empirical Analysis." Journal of Accounting and Economics 7 (April): 11-42.

Navarro, Peter. 1982. "Public Utility Commission Regulation: Performance, Determinants, and Energy Policy Impacts." The Energy Journal. 3 (April): 119-139.

Noll, Roger. 1989. "Economic Perspectives on the Politics of Regulation." In Richard Schmalensee and Robert Willig, eds., Handbook of Industrial Organization, vol. 2, pp. 1253-87. New York: North-Holland.

Peltzman, Sam. 1976. "Toward a More General Theory of Regulation." Journal of Law and Economics 19 (August): 211-40. 63-66.

1993. Comments. Brookings Papers on Economic Activity: Microeconomics, 1993:

Rose, Nancy and Andrea Shepard. 1994. " CEO Compensation and Diversification:Managerial Ability or Executive Entrenchment?" April (mimeo)

Rosen, Sherwin. 1992. "Contracts and the Market for Executives." In Lars Wernin and Hans Wijkander, eds., Contract Economics. Oxford: Basil Blackwell.

Sloan, Richard. 1993. "Accounting Earnings and Top Executive Compensation." Journal of Accounting and Economics, Volume 16, January/April/July.

Smiley, Robert and William Greene. 1983. "Determinants of the Effectiveness of Electric Utility Regulation." Resources and Energy 5 (March): 65-81. 
Stigler, George. 1971. "The Theory of Economic Regulation." Bell Journal of Economics and Management Science 2 (Spring): 3-21. 
TABLE 1: Descriptive Statistics

\begin{tabular}{|c|c|c|c|c|}
\hline VARIABLE: & & Mean & Std. Dev. & Observations \\
\hline \multirow[t]{2}{*}{ Compensation } & $S A L A R Y(\$ M)$ & 356.82 & 153.80 & 908 \\
\hline & TOTAL COMP. (\$M) & 387.96 & 199.32 & 908 \\
\hline \multirow{3}{*}{$\begin{array}{l}\text { CEO } \\
\text { Characteristics }\end{array}$} & CEO TENURE (years) & 6.53 & 4.64 & 908 \\
\hline & $A P T . A G E$ (years) & 50.88 & 5.74 & 908 \\
\hline & $\begin{array}{l}\text { OUTSIDER } \\
(1=\text { outsider })\end{array}$ & 0.15 & 0.36 & 908 \\
\hline \multirow{5}{*}{$\begin{array}{l}\text { Firm } \\
\text { Characteristics }\end{array}$} & MKT. RETURN & 0.23 & 0.22 & 908 \\
\hline & EXEMPT $(I=$ exempt $)$ & 0.15 & 0.35 & 908 \\
\hline & DIVERSE $(I=$ diverse $)$ & 0.12 & 0.33 & 908 \\
\hline & ASSETS $(\$ M M)$ & 5637.62 & 5111.69 & 908 \\
\hline & EMPLOYEES $(M)$ & 7.05 & 6.52 & 908 \\
\hline \multirow{12}{*}{$\begin{array}{l}\text { Measures of } \\
\text { Political } \\
\text { Pressure }\end{array}$} & SALOMON BROS & 6.60 & 2.09 & 908 \\
\hline & RES. RATE (\$/kwh) & 0.09 & 0.02 & 908 \\
\hline & IND. RATE (\$/kwh) & 0.06 & 0.02 & 908 \\
\hline & $\begin{array}{l}\text { RES. RATE GROWTH } \\
\left(\text { RES. RATE, RES. RATE } t_{l-\jmath}\right)-1\end{array}$ & 0.05 & 0.08 & 908 \\
\hline & $\begin{array}{l}\text { IND. RATE GROWTH } \\
\left(I N D . R A T E_{\ell} / I N D . R A T E_{r-1}\right)-1\end{array}$ & 0.05 & 0.10 & 908 \\
\hline & IND. CUSTOMERS (proportion) & 0.01 & 0.01 & 908 \\
\hline & IND. AVG. USE (gwh/cust) & 4.83 & 6.10 & 908 \\
\hline & ELECTED $(I=$ elected $)$ & 0.11 & 0.28 & 805 \\
\hline & TERM (years) & 5.65 & 1.18 & 805 \\
\hline & PUBLIC $(I=$ public $)$ & 0.67 & 0.43 & 805 \\
\hline & CHAIR SALARY (\$ M) & 70.94 & 13.43 & 805 \\
\hline & $\begin{array}{l}\text { NO QUALIFICATIONS } \\
(1=\text { no })\end{array}$ & 0.54 & 0.46 & 805 \\
\hline
\end{tabular}


TABLE 2: Estimates of CEO Salary Levels Including Measures of Polltical Pressure

Dependent Variable: $\ln (S A L A R Y)$

\begin{tabular}{|c|c|c|c|c|c|c|c|}
\hline MODEL: & $\mathbf{I}$ & II & III & IV & v & VI & VII \\
\hline CEO TENURE & $\begin{array}{c}.0195 \\
(.0025)\end{array}$ & $\begin{array}{c}.0198 \\
(.0025)\end{array}$ & $\begin{array}{c}.0196 \\
(.0024)\end{array}$ & $\begin{array}{l}.0195 \\
(.0025)\end{array}$ & $\begin{array}{c}.0195 \\
(.0025)\end{array}$ & $\begin{array}{l}.0195 \\
(.0023)\end{array}$ & $\begin{array}{l}.0194 \\
(.0023)\end{array}$ \\
\hline$A P T . A G E$ & $\begin{array}{c}.0061 \\
(.0030)\end{array}$ & $\begin{array}{l}.0064 \\
(.0028)\end{array}$ & $\begin{array}{l}.0065 \\
(.0028)\end{array}$ & $\begin{array}{c}.0061 \\
(.0029)\end{array}$ & $\begin{array}{c}.0061 \\
(.0029)\end{array}$ & $\begin{array}{c}.0067 \\
(.0028)\end{array}$ & $\begin{array}{l}.0067 \\
(.0028)\end{array}$ \\
\hline OUTSIDER & $\begin{array}{c}.0574 \\
(.0470)\end{array}$ & $\begin{array}{c}.0576 \\
(.0459)\end{array}$ & $\begin{array}{l}.0610 \\
(.0463)\end{array}$ & $\begin{array}{l}.0575 \\
(.0464)\end{array}$ & $\begin{array}{c}.0587 \\
(.0469)\end{array}$ & $\begin{array}{c}.0633 \\
(.0462)\end{array}$ & $\begin{array}{c}.0650 \\
(.0463)\end{array}$ \\
\hline MKT. RETURN & $\begin{array}{c}.0625 \\
(.0311)\end{array}$ & $\begin{array}{c}.0627 \\
(.0314)\end{array}$ & $\begin{array}{l}.0609 \\
(.0308)\end{array}$ & $\begin{array}{l}.0600 \\
(.0311)\end{array}$ & $\begin{array}{c}.0590 \\
(.0310)\end{array}$ & $\begin{array}{c}.0672 \\
(.0298)\end{array}$ & $\begin{array}{l}.0676 \\
(.0301)\end{array}$ \\
\hline$M K T . R E T U R N, t-1$ & $\begin{array}{c}.1297 \\
(.0333)\end{array}$ & $\begin{array}{l}.1352 \\
(.0336)\end{array}$ & $\begin{array}{l}.1363 \\
(.0329)\end{array}$ & $\begin{array}{l}.1307 \\
(.0332)\end{array}$ & $\begin{array}{c}.1315 \\
(.0332)\end{array}$ & $\begin{array}{l}.1393 \\
(.0330)\end{array}$ & $\begin{array}{l}.1400 \\
(.0330)\end{array}$ \\
\hline MKT. RETURN, t-2 & $\begin{array}{c}.1598 \\
(.0302)\end{array}$ & $\begin{array}{l}.1576 \\
(.0301)\end{array}$ & $\begin{array}{l}.1536 \\
(.0299)\end{array}$ & $\begin{array}{l}.1581 \\
(.0303)\end{array}$ & $\begin{array}{c}.1562 \\
(.0303)\end{array}$ & $\begin{array}{l}.1524 \\
(.0297)\end{array}$ & $\begin{array}{l}.1505 \\
(.0300)\end{array}$ \\
\hline EXEMPT & $\begin{array}{l}.1137 \\
(.0356)\end{array}$ & $\begin{array}{l}.1147 \\
(.0358)\end{array}$ & $\begin{array}{l}.1138 \\
(.0359)\end{array}$ & $\begin{array}{l}.1122 \\
(.0362)\end{array}$ & $\begin{array}{l}.1120 \\
(.0363)\end{array}$ & $\begin{array}{l}.1160 \\
(.0378)\end{array}$ & $\begin{array}{l}.1140 \\
(.0384)\end{array}$ \\
\hline DIVERSE & $\begin{array}{l}.1216 \\
(.0487)\end{array}$ & $\begin{array}{l}.1171 \\
(.0470)\end{array}$ & $\begin{array}{l}.1244 \\
(.0482)\end{array}$ & $\begin{array}{l}.1208 \\
(.0481)\end{array}$ & $\begin{array}{l}.1218 \\
(.0482)\end{array}$ & $\begin{array}{l}.1284 \\
(.0486)\end{array}$ & $\begin{array}{l}.1272 \\
(.0489)\end{array}$ \\
\hline $\ln (A S S E T S)$ & $\begin{array}{l}.1936 \\
(.0788)\end{array}$ & $\begin{array}{l}.2036 \\
(.0789)\end{array}$ & $\begin{array}{l}.1996 \\
(.0784)\end{array}$ & $\begin{array}{l}.1975 \\
(.0790)\end{array}$ & $\begin{array}{c}.1955 \\
(.0790)\end{array}$ & $\begin{array}{c}.2013 \\
(.0787)\end{array}$ & $\begin{array}{l}.2133 \\
(.0792)\end{array}$ \\
\hline $\ln (E M P L O Y E E S)$ & $\begin{array}{l}.1726 \\
(.1066)\end{array}$ & $\begin{array}{l}.1722 \\
(.1056)\end{array}$ & $\begin{array}{l}.1630 \\
(.1065)\end{array}$ & $\begin{array}{l}.1663 \\
(.1088) \\
\end{array}$ & $\begin{array}{r}.1658 \\
(.1087) \\
\end{array}$ & $\begin{array}{l}.1661 \\
(.1077)\end{array}$ & $\begin{array}{l}.1647 \\
(.1071) \\
\end{array}$ \\
\hline SALOMON BROS & $\begin{array}{c}. .0229 \\
(.0053)\end{array}$ & $\begin{array}{c}-.0245 \\
(.0055)\end{array}$ & $\begin{array}{c}-.0251 \\
(.0055)\end{array}$ & $\begin{array}{l}-.0239 \\
(.0056)\end{array}$ & $\begin{array}{l}-.0242 \\
(.0055)\end{array}$ & $\begin{array}{l}-.0250 \\
(.0058)\end{array}$ & $\begin{array}{l}-.0255 \\
(.0057)\end{array}$ \\
\hline $\ln (R E S . R A T E)$ & & $\begin{array}{l}-.1720 \\
(.0922)\end{array}$ & $\begin{array}{c}-.1122 \\
(.1074)\end{array}$ & & & $\begin{array}{l}-.1391 \\
(.1905)\end{array}$ & $\begin{array}{l}-.1515 \\
(.1899)\end{array}$ \\
\hline RES. RATE GROWTH & & & $\begin{array}{l}-.0541 \\
(.1005)\end{array}$ & & & $\begin{array}{l}-.2241 \\
(.1596)\end{array}$ & $\begin{array}{c}-.2371 \\
(.1582)\end{array}$ \\
\hline RES. RATE GROWTH, $1-1$ & & & $\begin{array}{l}-.2164 \\
(.0819)\end{array}$ & & & $\begin{array}{l}-.3007 \\
(.1304)\end{array}$ & $\begin{array}{l}-.3158 \\
(.1288)\end{array}$ \\
\hline $\ln (I N D . R A T E)$ & & & & $\begin{array}{c}-.0712 \\
(.0862)\end{array}$ & $\begin{array}{l}-.0705 \\
(.1041)\end{array}$ & $\begin{array}{r}.0529 \\
(.1770)\end{array}$ & $\begin{array}{r}.0654 \\
(.1770)\end{array}$ \\
\hline IND. RATE GROWTH & & & & & $\begin{array}{c}.0479 \\
(.0993)\end{array}$ & $\begin{array}{c}.1645 \\
(.1646)\end{array}$ & $\begin{array}{l}.1749 \\
(.1642)\end{array}$ \\
\hline IND. RATE GROWTH, $t-1$ & & & & & $\begin{array}{c}-.0714 \\
(.0772)\end{array}$ & $\begin{array}{l}.0914 \\
(.1193)\end{array}$ & $\begin{array}{l}.0995 \\
(.1187)\end{array}$ \\
\hline IND. CUSTOMERS & & & & & & & $\begin{array}{c}-2.827 \\
(1.410)\end{array}$ \\
\hline IND. AVG. USE & & & & & & & $\begin{array}{c}-.0003 \\
(.0015)\end{array}$ \\
\hline$\#$ of obs & 908 & 908 & 908 & 908 & 908 & 908 & 908 \\
\hline Adj. $R^{2}$ & .8819 & .8828 & .8834 & .8820 & .8820 & .8835 & .8838 \\
\hline
\end{tabular}

Robust standard errors in parentheses. All regressions include year- and firm-fixed effects. 
TABLE 3: Estimates of CEO Salary Levels Including Attributes of the State Regulatory Agency Dependent Variable: $\ln (S A L A R Y)$

\begin{tabular}{|c|c|c|c|c|}
\hline MODEL: & $E($ Sign) & VIII & $\mathbf{L X}$ & $\mathbf{x}$ \\
\hline CEO TENURE & & $\begin{array}{c}.0170 \\
(.0027)\end{array}$ & $\begin{array}{c}.0179 \\
(.0026)\end{array}$ & $\begin{array}{c}.0183 \\
(.0025)\end{array}$ \\
\hline$A P T . A G E$ & & $\begin{array}{r}.0056 \\
(.0033)\end{array}$ & $\begin{array}{c}.0063 \\
(.0032)\end{array}$ & $\begin{array}{r}.0068 \\
(.0030)\end{array}$ \\
\hline OUTSIDER & & $\begin{array}{c}.0454 \\
(.0498)\end{array}$ & $\begin{array}{c}.0506 \\
(.0488)\end{array}$ & $\begin{array}{c}.0558 \\
(.0485)\end{array}$ \\
\hline MKT. RETURN & & $\begin{array}{c}.0715 \\
(.0357)\end{array}$ & $\begin{array}{c}.0746 \\
(.0342)\end{array}$ & $\begin{array}{c}.0731 \\
(.0339)\end{array}$ \\
\hline MKT. RETURN, t-I & & $\begin{array}{c}.1363 \\
(.0365)\end{array}$ & $\begin{array}{c}.1301 \\
(.0349)\end{array}$ & $\begin{array}{c}.1362 \\
(.0343)\end{array}$ \\
\hline$M K T . R E T U R N, t-2$ & & $\begin{array}{c}.1884 \\
(.0357)\end{array}$ & $\begin{array}{c}.1783 \\
(.0338)\end{array}$ & $\begin{array}{c}.1714 \\
(.0338)\end{array}$ \\
\hline EXEMPT & & $\begin{array}{c}.0682 \\
(.0343)\end{array}$ & $\begin{array}{c}.0903 \\
(.0342)\end{array}$ & $\begin{array}{c}.0865 \\
(.0327)\end{array}$ \\
\hline DIVERSE & & $\begin{array}{l}.1096 \\
(.0452)\end{array}$ & $\begin{array}{l}.1128 \\
(.0461)\end{array}$ & $\begin{array}{l}.1173 \\
(.0456)\end{array}$ \\
\hline $\ln (A S S E T S)$ & & $\begin{array}{c}.2013 \\
(.0799)\end{array}$ & $\begin{array}{c}.2179 \\
(.0808)\end{array}$ & $\begin{array}{c}.2225 \\
(.0800)\end{array}$ \\
\hline $\ln (E M P L O Y E E S)$ & & $\begin{array}{c}.2134 \\
(.1028)\end{array}$ & $\begin{array}{c}.1883 \\
(.1026)\end{array}$ & $\begin{array}{r}.1764 \\
(.1020)\end{array}$ \\
\hline ELECTED & - & $\begin{array}{c}-.1770 \\
(.0775)\end{array}$ & $\begin{array}{c}-.1707 \\
(.0702)\end{array}$ & $\begin{array}{c}-.1589 \\
(.0613)\end{array}$ \\
\hline TERM & + & $\begin{array}{c}.0146 \\
(.0119)\end{array}$ & $\begin{array}{r}.0113 \\
(.0120)\end{array}$ & $\begin{array}{c}.0094 \\
(.0121)\end{array}$ \\
\hline PUBLIC & - & $\begin{array}{c}.0127 \\
(.0220)\end{array}$ & $\begin{array}{c}.0144 \\
(.0227)\end{array}$ & $\begin{array}{r}.0150 \\
(.0216)\end{array}$ \\
\hline $\ln (C H A I R$ SALARY) & + & $\begin{array}{c}.0850 \\
(.0826)\end{array}$ & $\begin{array}{c}.0215 \\
(.0831)\end{array}$ & $\begin{array}{c}.0211 \\
(.0833)\end{array}$ \\
\hline NO QUALIFICATIONS & - & $\begin{array}{c}-.0213 \\
(.0410)\end{array}$ & $\begin{array}{c}-.0512 \\
(.0394)\end{array}$ & $\begin{array}{r}-.0653 \\
(.0428)\end{array}$ \\
\hline SALOMON BROS & - & & $\begin{array}{c}-.0195 \\
(.0055)\end{array}$ & $\begin{array}{c}-.0222 \\
(.0057)\end{array}$ \\
\hline $\ln (R E S . R A T E)$ & - & & & $\begin{array}{r}-.1483 \\
(.1136)\end{array}$ \\
\hline RES. RATE GROWTH & - & & & $\begin{array}{c}-.0320 \\
(.1083)\end{array}$ \\
\hline RES. RATE GROWTH, $t-I$ & - & & & $\begin{array}{r}-.1760 \\
(.0871)\end{array}$ \\
\hline \# of obs & & 805 & 805 & 805 \\
\hline Adj. $\mathbf{R}^{2}$ & & .8872 & .8900 & .8914 \\
\hline
\end{tabular}

Robust standard errors in parentheses. All regressions include year- and firm-fixed effects. 


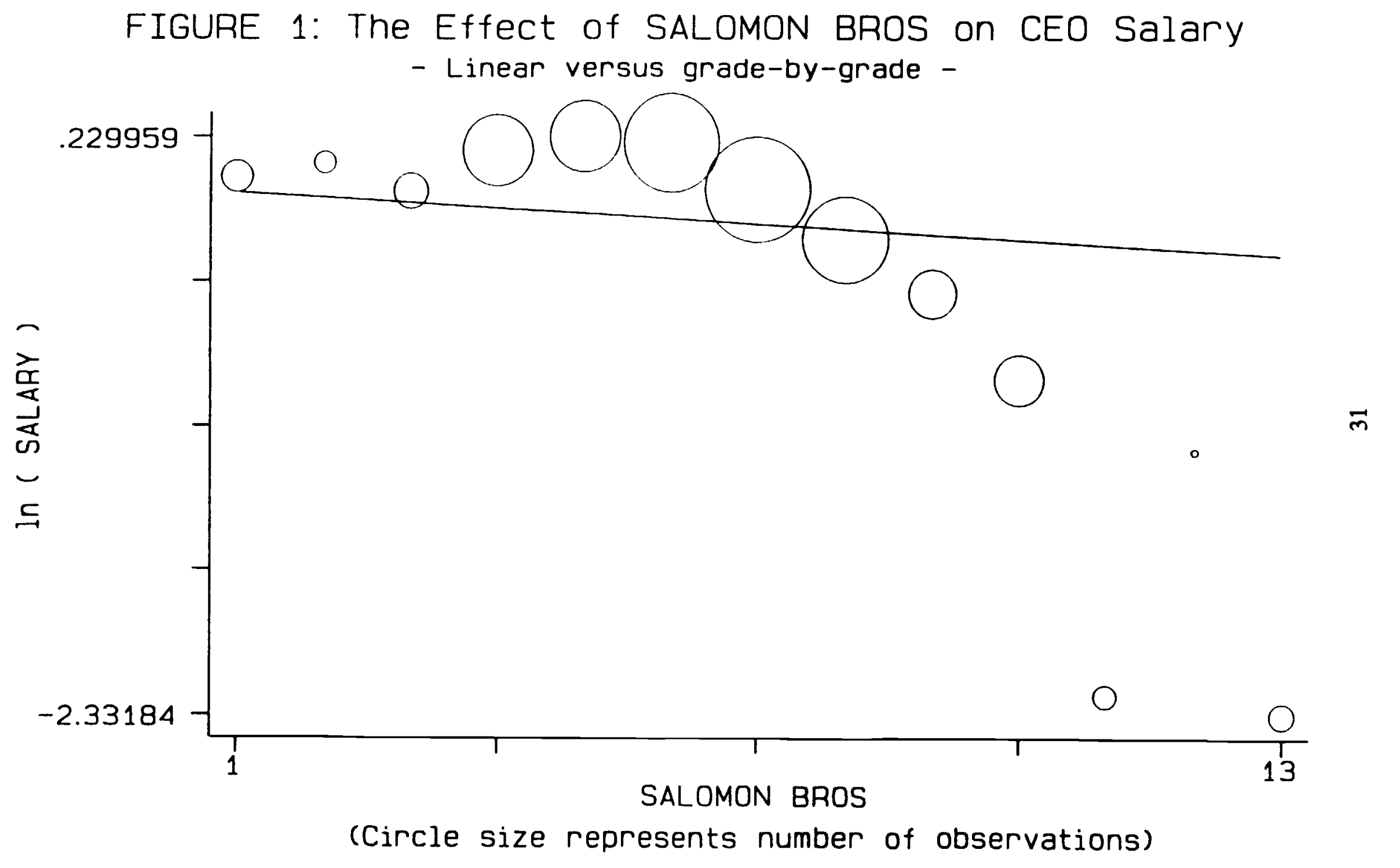

